\title{
Heavy metals (Cadmium, Mercury and Arsenic) accumulation in different organs of Sperata sarwari collected from Indus River, Head Taunsa, Dera Ghazi Khan, Punjab, Pakistan
}

Sabita Aamir ${ }^{1}$, Khalid Javed Iqbal ${ }^{1}$, Ammara Ehsan ${ }^{1}$, Zulqurnain ${ }^{2}$, Ghazala Kaukab $^{2}$, Abdullah Azeem ${ }^{3}$, Amna Tehseen ${ }^{1}$ and Muhammad $\operatorname{Asad}^{2 *}$

1. Department of Zoology, The Islamia University of Bahawalpur, Punjab 63100-Pakistan

2. Department of Zoology, Government College University Faisalabad, Punjab 38000-Pakistan

3. Faculty of Veterinary Sciences, University of Agriculture, Faisalabad, Punjab 38000-Pakistan

*Corresponding author's email: asad37iub@gmail.com

Citation

Sabita Aamir, Khalid Javed Iqbal, Ammara Ehsan, Zulqurnain, Ghazala Kaukab, Abdullah Azeem, Amna Tehseen and Muhammad Asad. Heavy metals (Cadmium, Mercury and Arsenic) accumulation in different organs of Sperata sarwari collected from Indus River, Head Taunsa, Dera Ghazi Khan, Punjab, Pakistan. Pure and Applied Biology. Vol. 9, Issue 2, pp1481-1487. http://dx.doi.org/10.19045/bspab.2020.90153

Received: 26/12/2019

Revised: 26/02/2020

Accepted: 08/03/2020

Online First: 10/03/2020

\section{Abstract}

This study was conducted to analyze the accumulation of cadmium, mercury and arsenic in different organs of Sperata sarwari. The fish were collected from Indus River, Head Taunsa, Dera Gazi Khan, Punjab, Pakistan. The organs of collected fish were separated and frozen at $-20{ }^{\circ} \mathrm{C}$. The organ samples were digested by using perchloric acid and nitric acid. The concentration of accumulated metals in organs was measured by using an atomic absorption spectrophotometer. The kidney was found most targeted organ for the accumulation of above mentioned heavy metals. All other organs also accumulate a significant amount of heavy metals. This study concludes that heavy metals of cadmium, mercury, and arsenic are found in the natural water and accumulate in different organs of Sperata sarwari.

Keywords: Arsenic; Cadmium; Kidney; Mercury Introduction

In developing countries fish is a cheap source of animal proteins and an important food world widely [1]. Fish is a complete diet package that provides energy having protein, amino acids, minerals and vitamins [2, 3]. Fish also protect against cardiovascular diseases and diabetes. Fish Contains omega-

3-fatty acids, docosahexaenoic acid (DHA) and eicosapentaenoic acid (EPA) [4]. If the fish is contaminated the health benefits of fish are useless and consumers may face adverse health problems [5].

Heavy metals are accumulated in river bed due to discharged wastewater from agriculture and industry. The suspended 
sediments in water absorbed heavy metals and absorbed heavy metals in turn release into different water channels. The outward flow of heavy metals from the mainstream poses a potential threat to the ecosystem [68]. The distribution of heavy metals also poses a risk to human health. $[9,10]$.

Fish are particularly limited to the aquatic environment and vulnerable to the effect of pollutants [11]. Fish is a test organism that indicates the ecosystem's health because fish is more sensitive to toxicants in comparison with invertebrate [12] Heavy metals are produced through anthropogenic and natural resources. The heavy metals pollution occurs through the process of weathering, deposition, waste discharge and also via wastewater treatment plants [13]. Considering the anthropogenic sources coal combustion is the source of emission of different heavy metals [14]. Heavy metals contamination is a serious threat due to long persistence nature, biomagnification and bioaccumulation in the food chain [15].

River pollution in Pakistan is increasing day by day due to rapid industrialization. The liquid influx of effluents from industries and domestic wastes adversely affects aquatic organisms [16]. Metallic pollution in rivers has been increased in recent years. Rivers are a hub for the growth of different animals and plant species. The accumulated metals in rivers move up to higher trophic levels through the food chain [17] Pollution in rivers is a cause of economic and health losses.

\section{Materials and methods Sampling}

Fish was collected from Head Taunsa, It is barrage situated on the Indus River, Taunsa, Dera Gazi Khan, Punjab, Pakistan. Fish was dissected and organs were separated. Organs were frozen in an icebox and shifted to the Department of Zoology, Islamia University of Bahawalpur. The organs were kept in the laboratory at $-20^{\circ} \mathrm{C}$ for further analysis.

\section{Sample digestion}

The organs were accurately measured (1g tissue) in a $100 \mathrm{ml}$ flask. $1 \mathrm{ml}$ perchloric acid and nitric acid were added and heated on a heating mantle to about $120^{\circ} \mathrm{C}$. The process ended when a clear and transparent solution was obtained. The digested samples were diluted using distilled water. The final volume of about $10 \mathrm{ml}$ was used after adding distilled water was used for analysis. The accumulation of metals was detected by the flame photometer method [18].

\section{Data analysis}

Data were analyzed using SPSS version 20. Means were compared by using Tukey's Test. One way ANOVA was applied ( $\mathrm{P}<$ 0.05 )

\section{Results \\ Cadmium}

Cadmium accumulation (ppm) was reported maximum in the kidney and liver, the value of $\mathrm{Cd}$ was $83.05 \pm 1.25$ and $82.45 \pm 0.85$ respectively in both organs. In gills, the accumulation $(77.15 \pm 1.07)$ was less as compared to kidney and liver but in muscles, the accumulation $(71.85 \pm 1.36)$ was lower as compared to the above-mentioned organs. In the skin, the accumulation of $\mathrm{Cd}$ was minimum (42.97 \pm 1.36$)$. The accumulation of $\mathrm{Cd}$ was found in this order Kidney $>$ Liver $>$ Muscles $>$ Gills $>$ Skin (Table 1, Fig. 1).

\section{Arsenic}

The accumulation of arsenic (ppm) was reported maximum in kidney and gills $0.63 \pm 0.02$ and $0.61 \pm 0.02$. The liver showed less accumulation of arsenic $(0.43 \pm 0.01)$ as compared to kidney and gill. In muscles, the accumulation $(0.32 \pm 0.01)$ of arsenic was more than the above-mentioned organs. In skin minimum, arsenic accumulation $(0.26 \pm 0.01)$ was reported. The accumulation of arsenic was found in this order Kidney > Gills $>$ Liver $>$ Muscles $>$ Skin (Table 1, Fig. 2). 


\section{Mercury}

Accumulation of mercury ( $\mathrm{ppm}$ ) was found maximum in kidney and liver $(2.66 \pm 0.02$ and $2.55 \pm 0.03$ ) while less accumulated in gills $(1.93 \pm 0.03)$ and muscles $(1.44 \pm 0.04)$. The minimum accumulation of mercury was reported in the skin $(0.93 \pm 0.02)$. Accumulation was found in the following order Kidney > Liver > Muscles > Gills > Skin (Table 1, Fig. 3).

Table 1. Concentration/Accumulation of cadmium, arsenic and mercury in different organs of Sperata sarwari (Singhari)

\begin{tabular}{|c|c|c|c|}
\hline Organs & Cadmium $(\mathbf{p p m})$ & Arsenic $(\mathbf{p p m})$ & Mercury $^{(\mathbf{p p m})}$ \\
\hline Kidney & $83.05 \pm 1.25^{\mathbf{A}}$ & $0.63 \pm 0.02^{\mathbf{A}}$ & $2.66 \pm 0.02^{\mathbf{A}}$ \\
\hline Muscles & $71.85 \pm 1.36^{\mathbf{C}}$ & $0.32 \pm 0.01^{\mathbf{C}}$ & $1.44 \pm 0.04^{\mathbf{D}}$ \\
\hline Gills & $77.15 \pm 1.07^{\mathbf{B}}$ & $0.61 \pm 0.02^{\mathbf{A}}$ & $1.93 \pm 0.03^{\mathbf{C}}$ \\
\hline Liver & $82.45 \pm 0.85^{\mathbf{A}}$ & $0.43 \pm 0.01^{\mathbf{B}}$ & $2.55 \pm 0.03^{\mathbf{B}}$ \\
\hline Skin & $42.97 \pm 1.36^{\mathbf{D}}$ & $0.26 \pm 0.01^{\mathbf{D}}$ & $0.93 \pm 0.02^{\mathbf{E}}$ \\
\hline
\end{tabular}

Similar alphabets in columns are insignificant and vice versa $(\mathrm{P}<0.05)$, ANOVA (Mean \pm Standard Deviation), Tukey's Test

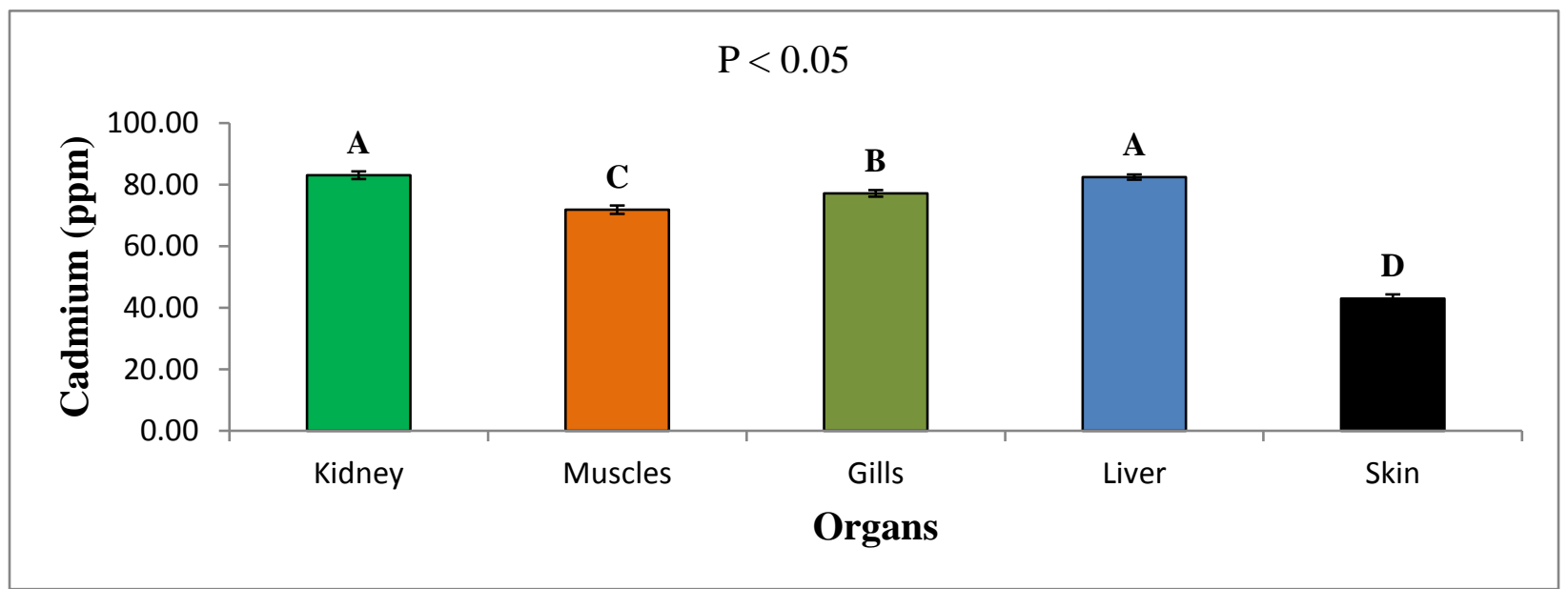

Figure 1. Concentration/Accumulation of cadmium in different organs of Sperata sarwari (Singhari)

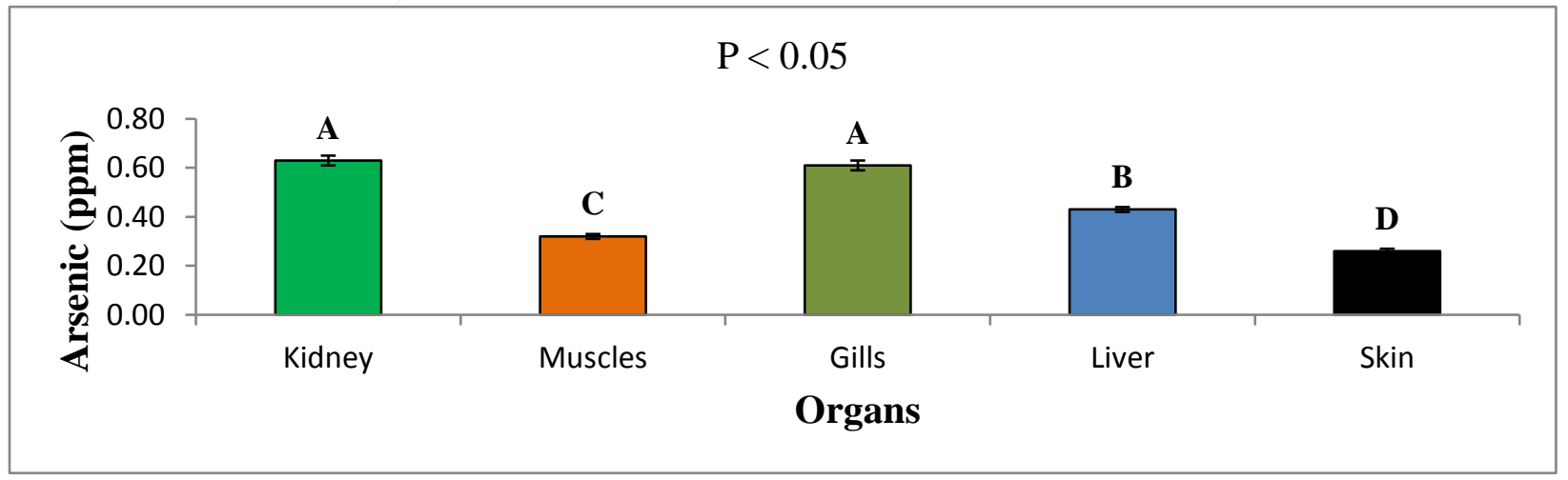

Figure 2. Concentration/Accumulation of arsenic in different organs of Sperata sarwari (Singhari) 


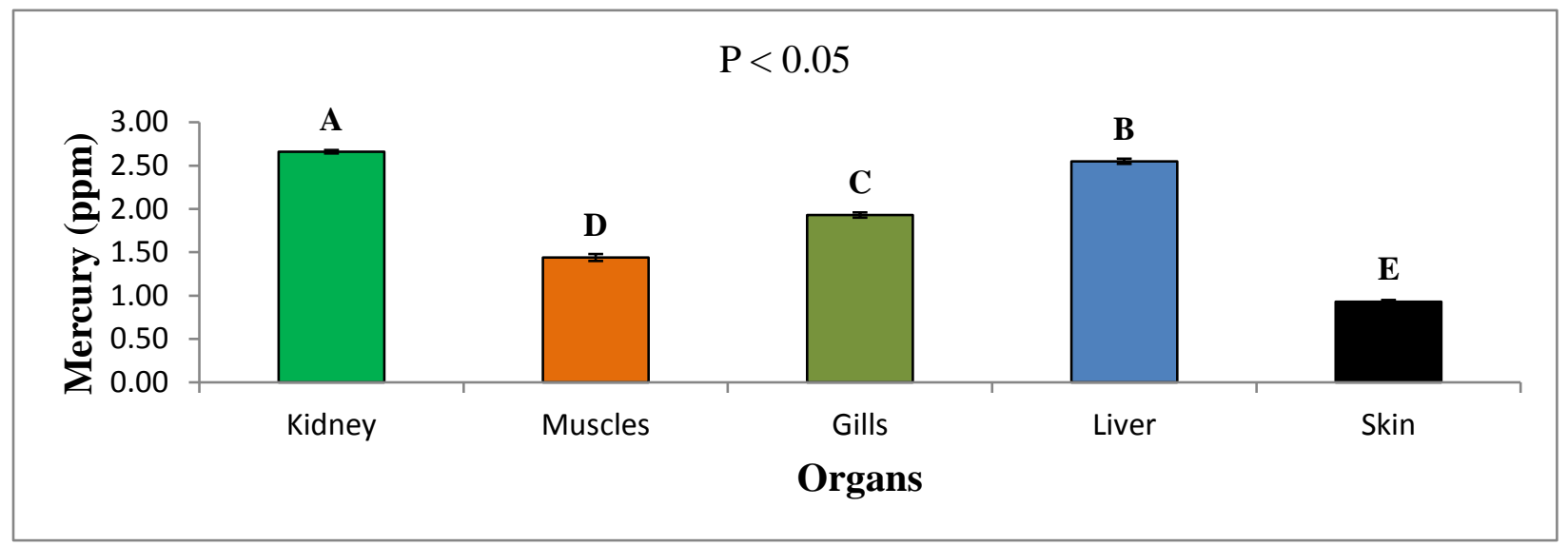

Figure 3. Concentration/Accumulation of mercury in different organs of Sperata sarwari (Singhari)

\section{Discussion}

Increasing development and the human population destroys the ecosystem especially the aquatic ecosystem. Heavy metals such as $\mathrm{Cu}, \mathrm{Cr}, \mathrm{Cd}$, and $\mathrm{Pb}$ accumulate in fish and other aquatic animals. Essential and nonessential metals both accumulated in different trophic levels of the food chain. Non-essential metals are known to be toxic for fish even at low concentration although they have no role in proper metabolic functioning. The management of heavy metal concentration is necessary because fish is consumed by a human in the world widely. The runoff water from different streams carries heavy metals and tends to accumulate in aquatic species and more commonly in fish [19].

Gills are the important site for the entry of heavy metals and act as indicator organs for the pollution of water. The accumulation of metals in gills may be due to metal interaction with mucus. The accumulated metals are difficult to remove from tissues. The accumulation of metals in organs indicates the presence of metals in water. Kidney and liver indicates the storage of metals [20]

The accumulation of metals in fish tissue related to the availability of metals in water, sediments, and food. Environmentally available cadmium has the ability to accumulate in tissues [21] According to Bervoets and Blust accumulation of metals in tissue indicates the presence of metals in the aquatic environment [22] Cadmium mainly enters fish through three main routes from gills, skin, and intestine [23] Different tissues have different abilities against metals accumulation [24, 25]. Many previous studies indicate the distribution of $\mathrm{Cd}$ in different fish tissues. The distribution of cadmium depends upon exposure route, dose and time, exceptions occur in different fish species [26]. According to our study the accumulation of cadmium found in river Sperata sarwari organs in the order as Kidney > Liver > Muscles > Gills > Skin. According to Ali et al., [25] the cadmium accumulation found in this order in different organs as muscle > brain > gills > liver > intestine > testis in experimental Gambusia holbrooki. The variations in both studies may be due to different fish species, analysis of different organs and the difference in experimental and river collected fish. Hollis et al [27] reported $\mathrm{Cd}$ accumulation in tissues in the order of kidney> gill > liver after 30 days of experiment in rainbow trout revealed similar observations for the kidney as maximum accumulation was reported but gills and liver were found in reverse order may be due to fish species and experimental 
difference. Atobatele and Olutona [28] reported a similar order of cadmium accumulation in different organs of fish in five different fish species collected from Aiba Reservoir, Iwo, Nigeria.

Mercury $(\mathrm{Hg})$ is a high persistence and harmful pollutant of the aquatic environment [29]. $\mathrm{Hg}$ accumulates in different aquatic organisms and magnifies through the food web [30]. Methyl mercury is the most available form of mercury in fish because it is easily uptake by the organisms and distribute among different tissues. The $\mathrm{Hg}$ mainly found in the liver and kidney [30]. Feeding patterns, fish activity, and trophic status are important parameters for mercury bioaccumulation [31]. In this study the mercury is accumulated in the organs as this order Kidney > Liver > Muscles > Gills > Skin

According to the study Atobatele and Olutona [28] the accumulation of $\mathrm{Hg}$ in different organs of different fish species was as Kidney > Liver > Gills > Intestine > Muscles. The accumulation of mercury was the same as for kidney and liver in the sequential order but not for the gills and muscles. The study of Atobatele and Olutona [28] resembles our study with minor deviations. The deviations were may be due to different studied fish species.

Arsenic accumulates in aquatic habitats and subsequently shifted to higher trophic levels. The arsenic may also target humans. Arsenic occurs in different organic forms and taken up by aquatic organisms. In inorganic form, arsenic is very toxic but its accumulation percentage is low. Arsenic accumulation depends upon the species and tissues [33] In the present study, the maximum amount of arsenic was found in the kidney and minimum in the skin. The accumulation order of arsenic in the studied fish was as Kidney > Gills $>$ Liver $>$ Muscles $>$ Skin. Kousar and Javed [34] reported arsenic accumulation in Common carp as Kidney > liver > fins > scales and Jabeen et al. [35] reported arsenic accumulation in Common carp as Liver > kidney $>$ intestine $>$ gonads $>$ skin. Similarly, Tyokumbur et al. [36] reported that arsenic accumulates in Clarias gariepinus as in this order Muscles $>$ liver $>$ gills $>$ bone $>$ gut $>$ fins. These studies resemble our study, the deviations in the present study when compared with other studies may be due to locality difference and also may be species difference.

\section{Conclusion}

This study concludes that heavy metals (Cadmium, Arsenic, and Mercury) accumulated in different organs of Sperata sarwari collected from Indus River, Head Taunsa, Dera Gazi Khan, Punjab, Pakistan. The accumulation of these metals in fish indicates that their concentration in the river increased day by day and is a risk for aquatic life which may affect human health indirectly.

\section{Authors' contributions}

Conceived idea: KJ Iqbal, Specimens collection: S Aamir \& A Ehsan, Analysed the data: Zulqurnain, Contributed materials/ analysis/ tools: G Kaukab \& A Azeem, Wrote the paper: M Asad, S Aamir \& A Tehseen

\section{References}

1. Nwani CD, Nwachi DA, Okogwu OI, Ude EF \& Odoh GE (2010). Heavy metals in fish species from lotic freshwater ecosystem at Afkpo, Nigeria. J Environ Biol 31: 595-601.

2. Rahman MS, Molla AH, Saha N \& Rahman A (2012). Study on heavy metals levels and its risk assessment in some edible fishes from Bangshi River, Savar, Dhaka, Bangladesh. Food Chem 134: 1847-1854.

3. Varol M, Kaya GK \& Alper A (2017). Heavy metal and arsenic concentrations in rainbow trout (Oncorhynchus mykiss) farmed in a dam reservoir on the Firat (Euphrates) River: risk-based consumption advisories. Sci Total Environ 599-600: 1288-1296. 
4. Storelli MM (2008). Potential human health risks from metals $(\mathrm{Hg}, \mathrm{Cd}$ and $\mathrm{Pb})$ and polychlorinated biphenyls (PCBs) via seafood consumption: estimation of target hazard quotients (THQs) and toxic equivalents (TEQs). Food Chem Toxicol 46(8): 2782-2788.

5. Fuentes-Gandara F, Pinedo-Herna'ndez J, Marrugo-Negrete J \& Di'ez S (2016). Human health impacts of exposure to metals through extreme consumption of fish from the Colombian Caribbean Sea. Environ. Geochem. Health 25(1): 639657.

6. Fang HW, Huang L, Wang JY, He GJ \& Reible D (2016). Environmental assessment of heavy metal transport and transformation in the Hangzhou Bay, China. J. Hazard. Mater 302: 447-457.

7. Zhu SQ \& Zang XP (2002). Heavy metal pollution along the Yangtze River stretches of urban area in major cities. Yangtze River 1: 62-66.

8. Varol M (2011). Assessment of heavy metal contamination in sediments of the Tigris River (Turkey) using pollution indices and multivariate statistical techniques. J Hazard Mater 195: 355-364.

9. Javed M \& Usmani N (2016). Accumulation of heavy metals and human health risk assessment via the consumption of freshwater fish Mastacembelus armatus inhabiting, thermal power plant effluent loaded canal. Springer Plus 5(1): 776.

10. Ke X, Gui S, Huang H, Zhang H, Wang C \& Guo W (2017). Ecological risk assessment and source identification for heavy metals in surface sediment from the Liaohe River protected area, China. Chemosphere 175: 473-481.

11. Saleh YS \& Marie MAS (2014). Assessment of metal contamination in water, sediment, and tissues of Arius thalassinus fish from the Red Sea coast of Yemen and the potential human risk assessment. Environ Sci Pollut $R$ 22(7): 5481-5490.
12. Abumourad IMK, Abbas WT, Authman MMN \& Girgis SM (2014) Environmental impact of heavy metal pollution on metallothionein expression in Nile Tilapia. Res J Pharm Biol Chem 5: 998-1005.

13. Dhanakumar S, Solaraj G \& Mohanraj R (2015). Heavy metal partitioning in sediments and bioaccumulation in commercial fish species of three major reservoirs of river Cauvery delta region, India. Ecotoxicol. Environ 113: 145-151

14. Wagner A \& Boman J (2003). Biomonitoring of trace elements in muscle and liver tissue of freshwater fish. Spectrochimica Acta Part B 58(12): 22152226.

15. Has-Schön E, Bogut I \& Strelec I (2006). Heavy metal profile in five fish species included in human diet, domiciled in the end flow of River Neretva. Arch Environ Con Tox 50: 545-551.

16. Javed M (2006). Studies on metal contamination levels in plankton and their role as biological indicator of water pollution in the river Ravi. Pak J Biol Sci 9(2): 313-317.

17. Robin RS, Mudulli PR, Vardhan K, Ganguly D, Abhilassh KR \& Balasubramanian T (2012). Heavy metal contamination and risk assessment in the marine environment of Arabian Sea along the southwest coast of India. Am J Chem 2: 191-208.

18. Wilson WJ \& Hausman R (1964). The determination of thallium in organs and body fluids by a flame spectrophotometric method. J Lab Clin Med 64(1): 154-159.

19. Eroglu A, Dogan Z, Kanak EG, Atli G \& Canli M (2015). Effects of heavy metals $(\mathrm{Cd}, \mathrm{Cu}, \mathrm{Cr}, \mathrm{Pb}, \mathrm{Zn})$ on fish glutathione metabolism. Environ Sci Pollut $R$ 22(5): 3229-3237.

20. Rajeshkumar S, Karunamurthy D, Halley G \& Munuswamy N (2015). An integrated use of histological and ultra-structural biomarkers in Mugil cephalus for assessing heavy metal pollution in east Berbice-Corentyne, Guyana. Inter J Bioassays 4(11): 4541-4554. 
21. Bervoets L, Blust R \& Verheyen R (2001). Accumulation of metals in tissues of threespined stickleback (Gasterousteus aculeatus) from natural fresh waters. Ecotoxicol Environ Saf 48: 117-127.

22. Bervoets L \& Blust R (2003). Metal concentrations in water, sediment and gudgeon (Gobio gobio) from a pollution gradient: relationship with fish condition factor. Environ Pollut 126: 9-19.

23. Karlsson-Norrgren L \& Runn P (1985). Cadmium dynamics in fish: Pulse studies with 109Cd $\mathrm{n}$ female Zebrafish, Brachydanio rerio. J Fish Biol 27: 571581.

24. Loumbourdis NS, \& Vogiatzis A.K (2002). Impact of cadmium on liver pigmentary system of the frog Rana ridibunda. Ecotoxicol Environ Saf 53: 5258.

25. Ali TH, Abed AA \& Abdul EA.(2018). Cadmium accumulation in some organs of mosquito fish Gambusia holbrooki. Tikrit J Pure Sci 21(1): 16-20.

26. Wu SM, Shih MJ \& Ho YC (2007). Toxicological stress response and cadmium distribution in hybrid tilapia (Oreochromis sp) upon cadmium exposure. Comp Biochem Phys A 145: 218-226.

27. Hollis L, Hogstrand C \& Wood CM (2001). Tissue-specific cadmium accumulation, metallothionein induction, and tissue zinc and copper levels during chronic sublethal cadmium exposure in juvenile rainbow trout. Arch Environ Con Tox 1: 468-474.

28. Atobatele OE \& Olutona GO (2015). Distribution of three non-essential trace metals (Cadmium, Mercury and Lead) in the organs of fish from Aiba Reservoir, Iwo, Nigeria. Toxicol Rep 2: 896-903.
29. Kehrig HA, Costa M, Moreira I \& Malm O (2002). Total and methylmercury in a Brazilian estuary, Rio de Janeiro. Marine Poll Bull 44: 1018-1023.

30. Liao CY, Fu JJ, Shi JB, Zhou QF, Yuan CG \& Jiang GB (2006). Methylmercury accumulation, histopathology effects, and cholinesterase activity alterations in medaka (Oryzias latipes) following sublethal exposure to methylmercury chloride. Environ Toxicol Phar 22: 225233.

31. Beckvar N, Field J, Salazar S \& Hoff R (1996) Contaminants in aquatic habitats at hazardous waste sites: mercury. US Dep. of Commer. NOAA Tech. Memo. NOAATM-NOS-ORCA 100: 74.

32. Kwaansa-Ansah EE, Adimado AA \& Ephraim JH (2012). Distribution of mercury in water, sediment and fish from the Volta Lake and its major tributaries. $J$ Environ Occup. Sci 1: 27-36.

33. Fattorini D, Bochetti R, Bompadre S \& Regoli F (2004). Total content and chemical speciation of arsenic in the polychaete Sabella spallanzanii. Mar Environ Res 58: 839-843.

34. Kousar S \& Javed M (2014). Heavy metals toxicity and bioaccumulation patterns in the body organs of four fresh water fish species. Pak Vet J 34(2): 161-164.

35. Jabeen G, Javed M \& Azmat H (2012). Assessment of heavy metals in the fish collected from the river Ravi. Pakistan. Pak Vet J 32(1): 107-111.

36. Tyokumbur ET, Okorie TG \& Umma BS (2014). Bioaccumulation of arsenic and uranium in two fish species (Clarias lazera and Tilapia zilli) from Alaro stream in Ibadan, Nigeria. Health Sci J 1(4): 6871. 